7. Kárpátaljai magyar népmesék. Szerk.: Lizanec Péter. Ungvár: Kárpáti Kiadó, 2019. 244 o.

8. Komáromi Gabriella. A gyermekkönyvek titkos kertje. Tanulmányok, esszék, kritikák. - Budapest: Pannonica Kiadó, 1998. 409 o.

9. Kovalovszky Miklós. Az irodalmi névadás. MNyTK 1934. № 34. 35-45. o.

10. Magyar grammatika. Szerk.: Keszler Borbála. Budapest: Nemzeti Tankönyvkiadó, 2000. 576 o.

11. Marosi Teréz. Tulajdonnevek a magyar népmesékben. Magyar Névtani Dolgozatok. № 13. 1981. 124-128 o.

12. P. Eőry Vilma. A népköltészet és a népnyelv hatása az irodalmi névadásra. Magyartanitás. Budapest, 2005. 266-74. o.

13. Rácz Borbála. Interjú Tarcsai Szabó Tiborral. Kézirat, 2007. 98 о. Офіц. веб-сайт. URL: http://www.tarcsaiszabo.hu/

14. Tolnai Vilmos. Beszélő nevek. Magyar Nyelv. №27. 1931.176-179 o.

15. Voigt Vilmos. A magyar mesei tulajdonnevek kis onomasztikája. Névtani Értesitö. №10. 1985.116-127 o.

16. Voigt Vilmos. Tulajdonnevek a magyar népmesékben. Névtani Értesitö. №15. 1993. 317-320 o.

УДК 81'373.421

DOI: $10.24144 / 2617-3921.2020 .18 .121-131$

Галина Онищак кандидат філологічних наук, дочент кафедри англійської філології ДВНЗ «УжНУ» orcid.org/0000-0002-5133-4313 Ужгород, Україна, +38(099) 0417763 halyna.onyshchak@uzhnu.edu.ua Діана Смужаниця кандидат філологічних наук, доцент кафедри іноземних мов ДВНЗ «УжНУ» orcid.org/0000-0002-3342-6927 Ужгород, Україна, +38(050)6550039 diana.smuzhanytsya@uzhnu.edu.ua

\title{
Особливості переносних значень іменників на позначення зла в сучасних французькій та українській мовах
}

Анотаиія. Стаття присвячена зіставному дослідженню переносних значень іменників на позначення зла в сучасних франиузькій та украйнській мовах. Міжмовне зіставлення проводиться за допомогою методики 
формалізованого аналізу лексичної семантики на матеріалі суцільного аналізу лексикографічних джерел. Проведене дослідження дало змогу скласифікувати лексичні одинииі на позначення зла, виявити їхні спільні та відмінні якісні й кількісні характеристики в двох далекоспоріднених мовах. Досліджувані слова займають важливе місие в лексичній системі франиузької та украйнської мов. Вони віддзеркалюють загальнолюдські поняття та водночас фіксують національно-специффічні иіннісні уявлення франиузів та українців про світ та їхне буття в ньому. Семантичний аналіз переносних значень іменників на позначення зла в сучасних франиузькій та украйнській мовах показав, щьо словникові значення слів містять неекспліковану інформачію, безпосередньо пов'язану з особою й навколишнім середовищем, досвідом і специфікою ї̈ пізнавальної діяльності. При зіставленні досліджуваних груп лексики у франиузькій та украӥнській мовах кількісні розходження превалюють над якісними. У досліджуваних мовах уявлення про форми реалізащіі зла, які вербалізуються переносними значеннями досліджуваних слів, частково збігаються. Таким чином, у обох мовах виділено групи іменників, щэо позначають психологічні, моральні та сочіальні характеристики реалізації зла. Основні культурні відмінності спостерігаємо у ставленні франиузів та украйнців до рис характеру людини та обставин реалізації зла. Такі відмонності пояснюються неоднаковим способом пізнання світу, а також побудовою мовної картини світу. На формування досліджуваної лексики виливають як лінгвальні, так $i$ екстралінгвальні чинники. Зміни, які відбуваються у лексичних значеннях іменників на позначення зла у франиузькій та українській мовах, можна пояснити динамікою изих мов та постійним розвитком їхньої структурної організації.

Ключові слова: переносне значення, формалізований аналіз, лексична семантика, лексична одиниия, якісні та кількісні характеристики, далекоспоріднені мови.

Abstract. The present article deals with the comparative study of the nouns' denoting evil figurative meanings in modern French and Ukrainian. The research has been carried out with the help of the formalized lexical semantics' analysis. Common and distinctive qualitative and quantitative characteristics of the lexical units in question in two distantly related languages have been revealed. The lexical units under research occupy an important place within the lexical system of the French and Ukrainian languages. They reflect common human notions and at the same time reveal nationally specific value images of the French and Ukrainians on the world and their existence in it. The semantic analysis of the words' denoting evil figurative meanings in modern French and Ukrainian has shown that dictionary meanings contain much inexplicit information, which is directly connected with a person and his/her environment, experience and specific character of his/her cognitive activity. While comparing the groups of words under research in French and Ukrainian, differences in quantitative characteristics prevail over qualitative 
ones. The comparative study has shown that forms and means of verbalizing evil by means of figurative meanings partly coincide in the language world pictures of the French and Ukrainians. Thus, the groups concerned with psychological, moral and social characteristics of evil realization have been singled out in both languages. The main cultural differences have been observed in the way the French and Ukrainians treat personal human characteristics and the circumstances of evil influence and realization. The differences can be explained by different ways of world cognition as well as the formation of language world picture. The lexis in question is influenced by both purely linguistic and extralinguistic factors. The changes in the meanings of the nouns under study can be explained by the dynamics of languages and the tendency to constant development of their structural organization.

Keywords: figurative meaning, formalized analysis, lexical semantics, lexical unit, qualitative and quantitative characteristics, distantly related languages.

Вступ. Сучасна лінгвістична наука відзначається появою міжмовних зіставних досліджень, спрямованих на виявлення спільних та відмінних семантичних ознак як споріднених, так і неспоріднених мов (I. О. Голубовська, В. В. Жайворонок, М. П. Кочерган, А. А. Лучик, М. П. Фабіан, A. Goddard, A. Wierzbicka, R. Jackendoff та ін.). Порівняння семантичного простору мов допомагає розкрити загальнолюдські універсалії і національну специфіку відображення навколишнього світу людини в їі свідомості, знайти ключ до пояснення ціннісних установок та мотивів поведінки як окремої людини, так і нації загалом: «семантична наповненість мови у цілому дорівнює сумі знань певного суспільства, що користується цією мовою, про людину і навколишній світ» [8, с. 22]. Намагаючись осягнути значення слова, ми «так чи інакше, приходимо до суті мовного образу світу, закріпленого в культурі» [1, с. 26]. Лексичні значення слів не тільки відображають особливості менталітету носіїв мови, але і здійснюють вплив на їхнє світосприйняття та поведінку.

У формуванні національної мовної картини світу значну роль відіграють переносні значення слів, адже їхне виникнення та розвиток зумовлюється особливостями національного світобачення та світосприйняття, ментальністю, ціннісними орієнтирами та установками етносу тощо. Семантична структура переносного значення містить компоненти різного плану, зокрема й оцінного, що відображають стереотипні незмінні уявлення й стійкі асоціації та активізуються в зв'язку із змінами культурних, національних, релігійних i політичних факторів. У цьому відношенні, виявлення міжмовних подібних та відмінних ознак переносних значень лексичних одиниць, що позначають аксіологічні поняття, зокрема добро і зло, у далекоспоріднених мовах, видається актуальним.

У сучасних лінгвістичних дослідженнях категорія «зло» досліджувалася в різних аспектах: структурно-семантичному - оцінний компонент у семантичній структурі слова (Г. І. Приходько); лінгвокогнітивному - 
категоріальний концепт (О. П. Лисицька); аксіологічному - в опозиції добро зло на матеріалі російської та французької мов (О. О. Богданова). Мовна реалізація прагматичного потенціалу дихотомії «добро - зло» в Біблії аналізувалася Д. В. Гурською. Проте, незважаючи на наявність наукових досліджень, у яких об'єктами аналізу постає лексико-семантична група «Зло», всі вони не вичерпують складнощів усебічного розкриття цього поняття, у зв'язку з чим проблема його комплексного науково обгрунтованого аналізу залишається актуальною й досі не вирішеною. Саме прикладний аспект дослідження поняття зла, зокрема через формалізоване його представлення у вигляді структури лексико-семантичної групи у французькій та українській мовах, сприятиме як розкриттю системних зв'язків між словами на позначення зла, так і виявленню специфіки репрезентації знань про феномен зла у свідомості носіїв цих мов.

Метою пропонованої статті $\epsilon$ розкриття особливостей вживання переносних значень іменників на позначення зла в сучасних французькій та українській мовах.

Поставлена мета передбачає розв'язання наступних завдань: 1) виявити специфіку передачі форм та засобів прояву зла переносними значеннями іменників в сучасних французькій та українській мовах; 2) виявити спільні та відмінні семантичні риси досліджуваних одиниць; 3) розкрити їхні якісні та кількісні характеристики.

Матеріал та методологія проведення дослідження. Матеріалом дослідження слугували лексичні одиниці, які містять експліцитні та імпліцитні вказівки на форми, основні характеристики і прояви зла, зібрані шляхом суцільного аналізу Grand Larousse de la Langue Française у 7-ми томах [18] та Словника української мови в 11-ти томах [9].

Дослідження іменників на позначення зла у французькій та українській мовах проводиться за допомогою методики формалізованого аналізу лексичної семантики (детальніше про методику роботи див. $[6 ; 10 ; 14 ; 15])$. Вказана методика базується на формальному, суто мовному критерії віднесеності слів, які аналізуються, до однієї частини мови - іменника [16, с. 37]. Семантичні відношення між словами представляємо у вигляді матриці, яку розглядаємо як метамову для опису досліджуваних об’єктів аналізу, в якій фіксується модель системи семантичних зв'язків, 3 одного боку, та семантичної структури лексики - 3 іншого. Тут розкриваються семантичні зв'язки між словами у вигляді стовпчиків та рядків однакової довжини, де знаком $(\diamond)$ позначаються співвідношення слів та їхніх значень.

Місця іменників на позначення зла в матриці строго фіксовані: слова 3 найвищим і середнім ступенем полісемії розташовані в густо заповнених іiі частинах, а з низьким ступенем та моносемічні - в рідко заповнених місцях. Разом із тим функціональне навантаження мають як заповнені, так i незаповнені клітини, а також віддаль між співвідносними словами та напрям їхнього розміщення. Таким чином, місце та роль іменників на позначення зла 
в системі сучасних французької та української мов визначається семантичним простором досліджуваної лексики, завдяки якому слова на позначення зла займають певне ієрархічне положення в семантичній системі мови: найбільш заповнена ділянка охоплює слова 3 найвищим ступенем полісемії, далі розташовуються іменники 3 середнім та низьким ступенем полісемії, а моносемічні лексичні одиниці представляють найменш заповнену його ділянку.

Міжмовне зіставлення іменників на позначення зла в досліджуваних мовах здійснюється шляхом зіставлення матриць, укладених внаслідок вивчення семантики зла в кожній із мов за ступенем полісемії та характером їхнього семного складу. За матрицею, в якій повною мірою представлено ступінь багатозначності лексем на позначення зла, та характер взаємозв'язків між ними, вивчаємо співвідношення досліджуваних слів у межах виділених груп, а також сем, виокремлених в їхніх лексичних значеннях, у межах виділених підмножин.

У нашому дослідженні системних відношень іменників на позначення зла, їхнього місця та ролі в сучасних французькій та українській мовах саме тлумачні словники виступають джерельною базою фактичного матеріалу, а дефініції досліджуваних слів у словнику служать базою для опису їхніх значень, де кожне окреме тлумачення представляє одне із значень досліджуваного слова. Словникова стаття є групою, в якій формальні ознаки строго організовані. Їхня кількість залежить від ступеня полісемії слова: чим вищим ступенем полісемії характеризується досліджувана одиниця, тим багатший набір формальних ознак. Таким чином, словникова стаття виступає комплексною формальною структурою, з якої не можна вилучити або до якої не можна додати жодної частини так, щоб не змінити інші частини і не викликати загального перегрупування [11, с. 204]. Слова на позначення зла в українській та французькій мовах $\epsilon$ сворідними точками опори, що допомагають носіям мови зайняти визначену позицію стосовно різноманітності явищ, через які й виявляється розуміння світу, будучи водночас його пізнанням та оцінюванням.

Виклад основного матеріалу дослідження. Вивчення лексики, яка вживається у переносних значеннях, вимагає розгляду того, як ці значення відрізняються між мовами і піднімає питання способів взаємозв'язку мовних та культурних моделей пов'язаних із пізнанням [13, с. 7]. Наявність переносного значення слова поряд із прямим свідчить про те, що воно здатне називати різні явища дійсності та відображати різноманітні поняття, збагачуючи семантичне наповнення мовних одиниць. У процесі актуалізації переносних значень, «мовці залучають уяву та креативне мислення, щоб осягнути абстрактні, або загальні знання» [12, с. 2]. Переносні значення можуть виникати внаслідок розбіжності між контекстуальною ситуацією та доречністю лексичної одиниці [19, с. 22]. 
Лексика, яка характеризується переносними значеннями, у складі лексико-семантичної групи «Зло» в сучасній французькій мові представлена 85 іменниками (20 \% усього лексичного складу на позначення зла), в українській - 91 (18,3\%). У процесі класифікації виділений нами лексичний склад у досліджуваних мовах поділяємо на групи за семантичним критерієм, що дає можливість виявити їхні спільні та відмінні риси й розкрити їхні якісні та кількісні характеристики.

Лексеми першої групи в обох мовах позначають людину-носія зла, яка характеризується певними негативними якостями, що підлягають осуду з боку суспільства. Досліджувані одиниці є характеризувальними метафорами, яким притаманна двоплановість метафоричного значення. Їхня основна функція полягає в оцінці та створенні чуттєвого образу. Слова gale, cauchemar, cholera та non-valeur вказують на злу (personne médisante, méchante), надокучливу (personne très ennuyeuse, très importune), неприємну людину (personne désagréale ou nuisible), з низьким рівнем інтелектуальних здібностей, яка не здатна виконати поставлене перед нею завдання (personne d'intelligence très médiocre, incapable d'assumer une tâche).

Лексика досліджуваної групи в українській мові демонструє більшу схильність до диференціації семантичних ознак: змій (про підступну, хитру людину; про злого, сильного $i$ підступного ворога), страхіття (людина незвичайного вигляду, ненормальних розмірів, ваги і т. ін.; людина з огидними моральними якостями), погань (негідна, нікчемна людина, що викликає зневагу, презирство), потвора (про люту, жорстоку $i$ m. ін. людину, щуо втратила кращі моральні якості; недолюдок), ворог (той, хто перебуває 6 стані ворожнечі, боротьби з ким-небудь; недруг, супротивник), личина (погана, зла, підступна людина), гидота (про підлу, мерзенну людину; погань), нечисть (негідні, нікчемні люди, перев. вороги, що викликають зневагу, презирство), мотлох (погані, негідні люди; набрід, наволоч), єхидна (про лиху, злу, хитру, лукаву, в'їдливу людину), звірота (про дуже жорстоких, лютих людей), паскуда (погана, мерзенна, підступна людина; жінка легкої поведінки). Для українців високі моральні якості людини мають велике значення, тому вони, показуючи своє негативне ставлення до того, що є злом, спонукають представників соціуму до добрих справ та дій на благо інших.

Лексичні одиниці другої групи доводять, що французька та українська психічні структури вирізняються емоційно-почуттєвим характером. Так, вони розкривають свою семантику завдяки вказівкам на: 1) дуже сильну емоцію (bouleversement: très vive émotion); 2) страждання (travail: épreuves, souffrances, convulsions qui accompagnent une laborieuse mutation; хрест: страждання, що випали на чиюсь долю); 3) горе (plaie: douleur, blessure morale; трагедія: велике горе, нещастя, загальнонародне чи особисте, спричинене гострим, непримиренним конфліктом); 4) роздратування (aigreur: irritation, mauvaise humeur passagère, provoquée par le dépit ou le ressentiment; agacement: légère irritation morale, qui provoque de l'impatience); 5) гіркоту 
(fiel: sentiment d'amertume qui accompagne certaines souffrances morales; осад: неприємне почуття гіркоти, що лишається після якої-небудь події, розмови $i$ m. ін.); 6) тривогу, неспокій (angoisse: inquiétude sans objet précis, accompagnée de sensations d'étouffement, de resserrement; каламуть: неспокій, тривога; malaise: état d'inquiétude vague, de gene, tourment d'esprit, effervescence); 7) збудження (гарячка: стан великого збудження); 8) хвилювання (hysterie: excitation, exaltation exagérée); 9) відчай, переживання (крик: про вияв відчаю, сильного душевного переживання; зашпори: переживання); 10) страх та біль (зашпори: страх, душевний біль).

Третю групу складають іменники, що позначають риси, дії та поведінку, які суперечать морально-етичним та соціальним нормам. Особистість не може жити поза суспільством, а отже, саме у суспільстві вона знаходить свою мету. Моральність як прояв індивідуальних рис та поведінки вимагає від індивіда дотримання суспільних норм та правил, які спричинюють певні протиріччя між моральністю та аморальністю як індивідуальною та суспільною категорією.

Досліджувані лексичні одиниці у зіставлюваних мовах демонструють різне семантичне наповнення. Французи ототожнюють зло з порочністю (contamination: transmission à d'autres de tares morales, de vices, de défauts), відхиленням від моральних норм (corruption: altération morale, dérèglement des moeurs; maladie: ce qui apporte une perturbation dans les facultés intellectuelles ou morales; déviation: action de s'écarter de certains principes, moraux, philosophiques ou politiques), грубим, принизливим вчинком (ordure: acte, grossier, indigne, dégradant), що призводить до порушення моральних принципів (désordre: dérèglement de la conduite, des moeurs) і навіть знищення чи смерті (assassinat: action provoquant la disparition, l'anéantissement injuste de quelque chose).

Представники української лінгвокультури визначають його як швидку, разючу дію (удар (вдар)), зловмисність, прикриту показною доброзичливістю (підступ), раптову примху, безпідставну, непослідовну дію, нечемний вчинок, вислів (вибрик), бузувірський вчинок (бузувірство), нестриманість (розпущеність), аморальну, жорстоку поведінку, варварство (дикунство), щзо-небудь розтлінне, порочне, аморальне (гниль).

Така розрізненість понять пояснюється тим, що людина оволодіває моделями поведінки завдяки досвіду, характерному для того соціуму, в якому вона живе. Позаяк кожна мова $є$ «автономною системою» $[15$, с. 10], як у французькій, так в українській мовах наявні обумовлені культурою лексичні одиниці, які містять інформацію про екзистенціальні знання лінгвокультурної спільноти.

Семантика поганого ставлення та стосунків розкривається іменниками п'ятої групи. Серед них виділяємо такі, які позначають безчестя (flétrissure: atteinte ignominieuse à l'honneur, à la réputation de quelqu'un), приниження (mortification: froissement d'amourpropre, humiliation), жорстоку критику 
(éreintement: critique violente et dénigrante), недоброзичливе, жорстоке ставлення (indisposition: disposition peu favorable envers quelqu'un; бузувірство: жорстоке ставлення до кого-, чого-небудь), зіпсовані стосунки (altération: dégradation de la santé, d'un sentiment, des relations entre les personnes), ворожість, злобу (жовч: почуття ворожості, недоброзичливості; злоба).

Шоста група нашого мовного матеріалу містить лексичні одиниці, об'єднані причинно-наслідковими зв'язками. Сюди відносимо іменники, що інтерпретують передумови та наслідки зла шляхом вказівки на: 1) перешкоду (embarrass: obstacle qui empêche d'agir, ou qui arrête la réalisation de quelque chose; перепона: те, шо перешкоджає здійсненню чого-небудь; перешкода); 2) нещастя, горе (fléau: grande calamité publique; трагедія: велике горе, нещастя, загальнонародне чи особисте, спричинене гострим, непримиренним конфліктом); 3) неуспіх, невдачу чи провал (fallite: insuccès constaté, patent, d'une entreprise, d'un système, d'une idée; поразка: невдача в боротьбі за щонебудь, у якійсь справі і т. ін.; провал: невдале, безуспішне, не таке, як хтось бажав, закінчення, завершення чого-небудь; аварія: невдача, несподіване порушення ходу якоїсь справи; банкрутство: неспроможність, провал у чомунебудь); 4) безвихідну, несприятливу ситуацію (cul-de-sac: entreprise, situation, carrière qui ne mène à rien; impasse: situation qui ne présente pas d'issue favorable; западня: безвихідне $i$ загрозливе становище, в яке потрапляє хтонебудь унаслідок певних, звичайно хитрих, підступних дій когось); 5) смерть (mort: qui est considéré comme déjà mort, parce qu'il est en danger de mort ou parce qu'il ne mène plus une vie active; смерть: загибель, припинення існування чого-небудь; кінець: смерть, загибель; кирпа: смерть) тощо.

Лексеми сьомої групи підкреслюють соціопрагматичний характер зла, розкриваючи семантику суспільного безладдя (confusion: désordre, manque de clarté dans le domaine intellectuel; chaos: désordre social, politique; анархія: безладдя, хаос), розбіжностей та конфліктів (conflit: antagonisme, opposition de sentiments, d'opinions, de tendances contradictoires, chez la même personne; collision: opposition, rivalité aiguë; combat: opposition, violente ou non, des éléments, des forces naturelles; зачіпка: суперечка, сварка; гризня: сварка, лайка у людей; гострі суперечки між протилежно настроєними групами людей; боротьба: зіткнення у свідомості людини протилежних думок, почуттів $i \mathrm{~m}$. ін.), збройного нападу, боротьби та війни (agonie: chute, disparition, malgré une résistance, une lute; bataille: lutte qui oppose des personnes, des partis, des groupements, ou combat qu'engage un individu contre des difficultés; assaut: se dit de ce qui attaque avec violence (éléments, passions, etc.); бій: боротьба за шь-небудь; війна: стан ворожнечі між ким-небудь; суперечка, сварка з кимсь; боротьба).

Цікавою, на наш погляд, $є$ семантика іменників crise, complicité, auspice, délire, безумство, завоювання, чорт, позаяк їхні переносні значення, характеризуючись позитивною оцінною семантикою, протиставляються 
прямим: accès d'enthousiasme, manifestation soudaine et violente d'un sentiment; ensemble de circonstances favorables; circonstances favorables, avec toutes les chances de succès; état d'agitation extrême, d'exaltation causé par un sentiment violent, et surtout par la joie, l'enthousiasme; надзвичайна відвага, рішучість у вчинках; перемога, досягнення, успіх, здобуті у боротьбі, праці і т. ін.; хтонебудь умілий, жвавий, меткий, хитрий, сміливий. Наявність позитивно маркованих одиниць серед нашого мовного матеріалу свідчить про перетин лексико-семантичної групи «Зло» 3 лексико-семантичною групою «Добро», що вказує на наявність перехідних зон між вказаними поняттями, які забезпечують недискретність категоріального простору. Таким чином, перетин зумовлений складністю семантичної структури слова та багатофакторністю формування оцінних категорій, які мають нечіткі межі й «розмитий», залежний характер.

Особливістю досліджуваної лексики в українській мові $є$ те, що вона представлена синонімічними одиницями та виявляє схильність до їхньої іррадіації, суть якої полягає в тому, що якщо одне зі слів у групі змінило своє значення на переносне, то й інші синонімічні слова того ж семантичного угруповання піддаються цьому процесу й починають набувати таких самих переносних значень для пояснення певного кола спільних ідей, понять чи символів. Прикладом такого явища слугують лексичні значення іменників прах та руїна, які в переносному значенні позначають залишки давніх часів $i$ звичаїв та те, що залишилось, уціліло від чого-небудь, щэо зникло, минуло, а також тьма та пітьма, які збігаються у семантиці неосвіченості, відсталості у культурному відношенні.

Серед відмінних семантичних ознак переносних значень слів на позначення зла відносимо передачу поганого характеру людини (insolence: caractère insolent, provocant, de quelque chose; inférioté: caractère d'une personne ou d'une chose inférieure à une autre; morbidité: caractère malsain) та матеріальної і моральної шкоди (outrage: dommage ou tort causé aux êtres ou aux choses; casse: dommage moral résultant d'une rupture entre personnes, d'une dispute, etc.) у французькій мові, та труднощів, клопотів (терни: про труднощі, злигодні, страждання на життєвому шляху людини; тягар: дуже важкі обов'язки, знегоди, клопоти; ярмо: тягар, ноша; гніт: тягар), втомливої праці та важкого життя (каторга: надзвичайно важка, зморна праия; тяжке, нестерпне життя), несприятливих обставин (пекло: нестерпні, жахливі умови, обставини) - в українській.

Проведений лексико-семантичний аналіз слів на позначення зла у французькій та українській мовах показав, що лексичні значення досліджуваних одиниць відтворюють загальнолюдське та національнокультурне, метафорично-символічне та асоціативно-оцінне, традиційно народне та особистісно визначене бачення феномену зла. Відмінності у його розумінні французами та українцями зумовлені своєрідністю дискретизації 
світу, що відображає неоднаковий спосіб його пізнання французькою та українською етноспільнотами.

Висновки. Одну з найдавніших груп лексикону кожної мови становлять аксіологічні поняття, які не тільки слугують засобом фіксації усталених поглядів на моральні та етичні цінності, але й віддзеркалюють світоглядні уявлення народу, формуючи важливу складову його мовної картини світу. Розуміння сутності зла відноситься до найбільш складних та гострих питань в сучасному суспільстві, адже охоплює як повсякденний, так і суспільноправовий простір людської свідомості.

Зіставний аналіз переносних значень слів на позначення зла у французькій та українській мовах показав, що досліджуваним іменникам притаманна надзвичайна семантична мобільність, яка полягає в пристосуванні до лексичних одиниць різної семантики, набуваючи похідних, вторинних значень, які розповсюджуються на всі предмети і явища, розширюючи сферу свого семантичного вживання.

Як у французькій, так і в українській мовах переносні значення слів на позначення зла володіють сукупністю актуальних ознак, які складають базові уявлення про зло, та $\epsilon$ культурно і соціально значущими. Характеристики зла в значній мірі співпадають у французькій та українській мовах. Так, воно розглядається як сукупність психологічних та соціальних характеристик, поведінкових стереотипів та культурний феномен.

Перспективи подальших розвідок вбачаємо в залученні до розкриття семантики зла інших як далекоспоріднених, так і неспоріднених мов.

\section{ЛІТЕРАТУРА}

1. Бартминский Е. Языковой образ мира : очерки по этнолингвистике. Москва : Индрик, 2005. 528 с.

2. Голубовська I. О. Етнічні особливості мовних картин світу : монографія. Київ : Логос, 2004. Вид. 2-е, випр. і доп. 284 с.

3. Жайворонок В. В. Українська етнолінгвістика: Нариси. Київ : Довіра, 2007. $262 \mathrm{c}$.

4. Кочерган М. П. Основи зіставного мовознавства. Київ : Академія, 2006. $424 \mathrm{c}$.

5. Лучик А. А. Компонентний аналіз у зіставних дослідженнях лексичних одиниць. Сучасні дослідження з іноземної філології. Ужгород, 2009. Вип. 7. С. 258-262.

6. Онищак Г. В. Системно-структурна параметризація лексикосемантичної групи «Зло» в українській, англійській та французькій мовах : дис. на здоб. наук. ступ. канд. філол. наук. : спец. 10.02.15 «Загальне мовознавство». Київ, 2018. 360 с. 
7. Приходько Г. І. Оцінний компонент в семантичній структурі слова. Наукові записки. Серія : Філологічні науки (мовознавство). Кіровоград : КДПУ, 2005. Вип. 59. С. 145-152.

8. Русанівський В. М. Структура лексичної і граматичної семантики / відп. ред. О. С. Мельничук. Київ : Наук. думка, 1988. 240 с.

9. Словник української мови : у 11 т. / І. К. Білодід та ін. Київ : Наукова думка. 1970-1980.

10. Фабіан М. П. Етикетна лексика в українській, англійській та угорській мовах : монографія. Ужгород : Інформаційно-видавниче агентство «IBA», 1998. $255 \mathrm{c}$.

11. Фабіан М. П. Застосування процедури формалізованого аналізу лексичної семантики в зіставних дослідженнях. Проблеми зіставної семантики. Київ, 2011. Вип.10, ч. І. С. 202-207.

12. Athanasiadou A. Studies in Figurative Thought and Language. Amsterdam : John Benjamins Publishing Company, 2017. 327 p.

13. Dancygier B., Sweetser E. Figurative Language. Cambridge : CUP, 2014. $242 \mathrm{p}$.

14. Fabian M. P. Comparative Research of Etiquette Nouns in English, Ukrainian and Hungarian. Development of Philology and Linguistics at the Modern Histirical Period: Collective Monograph. Lviv-Torun: Liha Pres, 2019. P. 161-179.

15. Fabian M. P. Lexical Semantics: New Approach to Its Study. Journal of Interdisciplinary Philology (1-2). Žilina : Univ. of Žilina Publ.House, 2013. P. 5-12.

16. Fabian M. P. Structural Approach to the Study of Meaning (on the material of adjectives in modern Ukrainian). Philosophy of Language and New Trends in Translation Studies and Linguistics: Collective Monograph. Lviv-Torun: Liha Pres, 2019. P. 34-51.

17. Goddard C., Wiezbicka A. Words and Meanings. Lexical Semantics across Domains, Languages and Cultures. UK : Oxford Uniersity Press, 2014. 314 p.

18. Grand Larousse de la Langue Française : en 7 vol. / sous la direction de L. Gilbert, R. Lagane, G. Niobey, avec le concours de H. Bonnard, L. Casati, A. Lerond. Paris : Larousse, 1986. 6528 p.

19. Philip G. Colouring Meaning : Collocation and Connotation in Figurative Language. Amsterdam / Philadelphia : John Benjamins Publishing, 2011. 232 p.

20. Wierzbicka A. Cross-Cultural Pragmatics : The Semantics of Human Interaction. Berlin : Mouton de Gruyter, 2003. 501 p. 